\title{
Indian Ocean Warming
}

\section{Coordinating Lead Authors}

M. K. Roxy, Indian Institute of Tropical Meteorology (IITM-MoES), Pune, India C. Gnanaseelan, Indian Institute of Tropical Meteorology (IITM-MoES), Pune, India, e-mail: seelan@tropmet.res.in (corresponding author)

\section{Lead Authors}

Anant Parekh, Indian Institute of Tropical Meteorology (IITM-MoES), Pune, India Jasti S. Chowdary, Indian Institute of Tropical Meteorology (IITM-MoES), Pune, India Shikha Singh, Indian Institute of Tropical Meteorology (IITM-MoES), Pune, India Aditi Modi, Indian Institute of Tropical Meteorology (IITM-MoES), Pune, India Rashmi Kakatkar, Indian Institute of Tropical Meteorology (IITM-MoES), Pune, India Sandeep Mohapatra, Indian Institute of Tropical Meteorology (IITM-MoES), Pune, India Chirag Dhara, Indian Institute of Tropical Meteorology (IITM-MoES), Pune, India

\section{Review Editors}

S. C. Shenoi, Indian National Centre for Ocean Information Services (INCOIS-MoES), Hyderabad, India

M. Rajeevan, Ministry of Earth Sciences, Government of India, New Delhi, India

\section{Corresponding Author}

C. Gnanaseelan, Indian Institute of Tropical Meteorology (IITM-MoES), Pune, India, e-mail: seelan@tropmet.res.in 


\section{Key Messages}

- The tropical Indian Ocean has experienced rapid basin-wide sea surface temperature (SST) warming, with an average rise of $1.0{ }^{\circ} \mathrm{C}\left(0.15^{\circ} \mathrm{C} /\right.$ decade $)$ during $1951-$ 2015, over which period the global average SST warmed about $0.7{ }^{\circ} \mathrm{C} \quad\left(0.11^{\circ} \mathrm{C} /\right.$ decade $)$ (high confidence). The SST warming is spatially non-uniform and about $90 \%$ of the warming is attributed to anthropogenic emissions.

- The basin-wide non-uniform SST warming trend in the tropical Indian Ocean is to continue in the future, under both medium and high emission scenarios (high confidence)

- The frequency of extreme positive Indian Ocean Dipole (IOD) events is projected to increase by almost a factor of three, with one-in-seventeen-year events in the twentieth century to one-in-six-year by the end of the twenty-first century (low confidence).

- The heat content of the upper $700 \mathrm{~m}$ of the Indian Ocean has exhibited an increasing trend during 1955-2015 (high confidence), with spatially non-uniform heating.

- SST warming has very likely contributed to the decreasing trend observed in oxygen $\left(\mathrm{O}_{2}\right)$ concentrations in the tropical Indian Ocean, and the declining trend in $\mathrm{pH}$ and marine phytoplankton over the western Indian Ocean. These trends are projected to continue with global warming.

\subsection{Introduction}

About one third of the global population lives around the Indian Ocean-many in low-lying coastal regions, small islands or low-to-middle income nations with low adaptive capacity - that are especially vulnerable to climate change impacts. Ocean-atmospheric conditions over the Indian Ocean regulate the regional weather-climate system over these regions. Hence, variability and changes in this basin are of great significance to the food, water and power security in India and neighbouring countries.

Warm sea surface temperatures (SSTs $>28{ }^{\circ} \mathrm{C}$ ), known as the Indian Ocean warm pool, occur over a large part of the tropical Indian Ocean (TIO, $40{ }^{\circ} \mathrm{E}: 115{ }^{\circ} \mathrm{E} ; 30{ }^{\circ} \mathrm{S}: 30{ }^{\circ} \mathrm{N}$ ), which is a part of the larger Indo-Pacific warm pool. It favours deep atmospheric convection (Graham and Barnett 1987) and energizes the global atmospheric circulation, particularly the Hadley circulation and the Walker circulation thereby modulating the major elements of global climate such as the Indian monsoon and the El Niño Southern Oscillation (ENSO). The strong monsoon winds during
June-July-August-September force intense coastal and open-ocean upwelling in the Arabian Sea, and modulate evaporation and moisture transport towards India (Izumo et al. 2008). They also provide a globally significant source of atmospheric $\mathrm{CO}_{2}$ (Valsala and Murtugudde 2015), and foster intense marine primary productivity (Roxy et al. 2016). Unlike the other tropical ocean basins, the Indian Ocean is landlocked in the north by the vast Asian landmass and hence the only trans-basin exchanges are from the West Pacific via the Indonesian Seas, known as the Indonesian Through flow (ITF), and from the south.

The rate of warming in the tropical Indian Ocean is the fastest among tropical oceans and accounts for about one quarter of the increase in global oceanic heat content over the last two decades (Beal et al. 2019) despite being the smallest of the tropical oceans (representing only $13 \%$ of the global ocean surface). The Indian Ocean is home to $30 \%$ of the world's coral reefs and $13 \%$ of global wild-catch fisheries. This marine ecosystem, including corals and phytoplankton, and fisheries are being impacted by a rise in heat waves in the ocean, known as marine heat waves (Collins et al. 2019). Moreover, an expansion of the Indian Ocean warm pool is changing the subseasonal weather variability such as the monsoon intraseasonal oscillation (Sabeerali et al. 2014) and the Madden-Julian oscillation (Roxy et al. 2019), which originate in the Indian Ocean. This has an impact on rainfall characteristics, particularly on extreme rain over the tropics, including India. Heat waves (Chap. 2), droughts and floods (Chap. 6), tropical cyclones (Chap. 8) and extreme sea-level changes (Chap. 9) are becoming more frequent and intense around the Indian Ocean as regional climate patterns respond to anthropogenic climate change (Collins et al. 2019). Hence, there is an urgent need to understand the status and future evolution of the Indian Ocean warming and its role in influencing the regional climate under a global warming environment.

\subsection{Observed and Projected Changes in Indian Ocean SST}

\subsubsection{Observed Changes in SST}

The oceans have absorbed approximately $93 \%$ of the additional heat due to anthropogenic global warming since the 1950s (Cheng et al. 2017) and have resulted in a significant increasing trend in the global average ocean SST, as evidenced by modern instrumental records (Deser et al. 2010). Among the oceans, Indian Ocean stands out as one of the most rapidly warming ocean basins (Gnanaseelan et al. 2017; Beal et al. 2019). The global average rise in SST 


\section{(a) ERSSTV4 (1951-2015)}

$\left({ }^{\circ} \mathrm{C} /\right.$ decade $)$

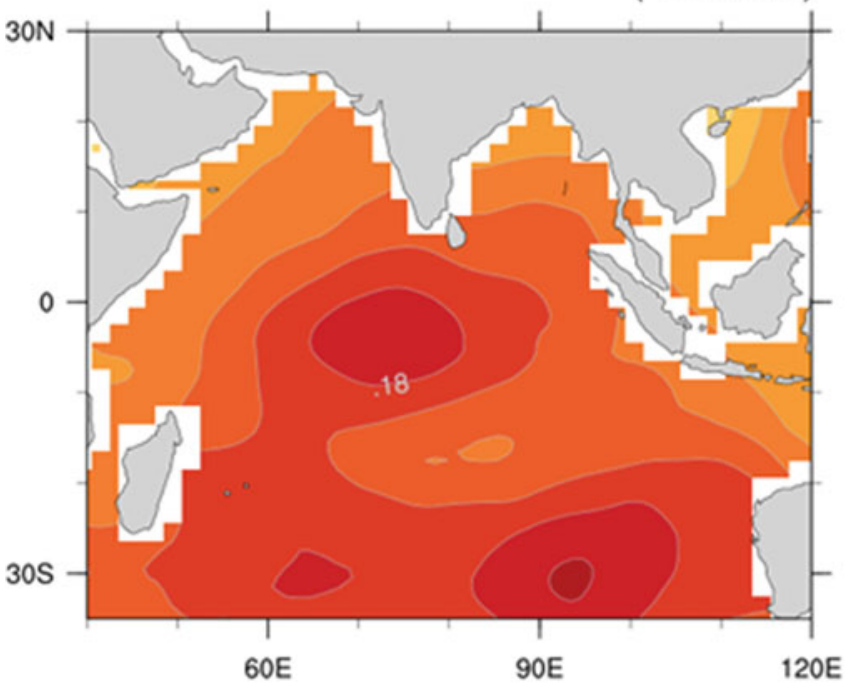

(b) Historical (1976-2005)

$\left({ }^{\circ} \mathrm{C} /\right.$ decade $)$

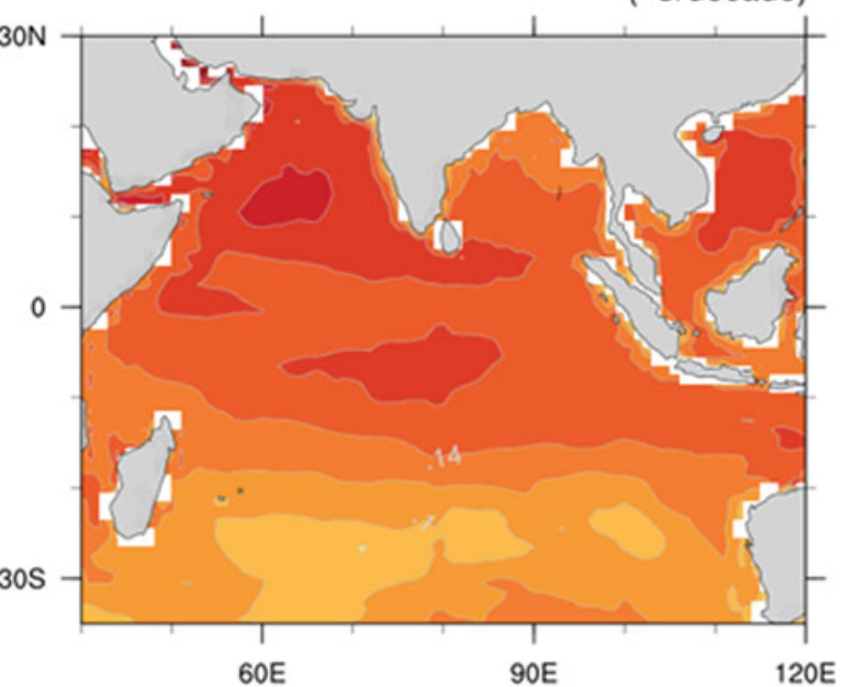

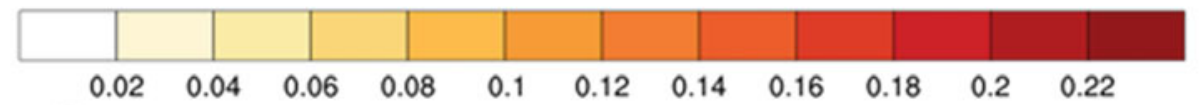

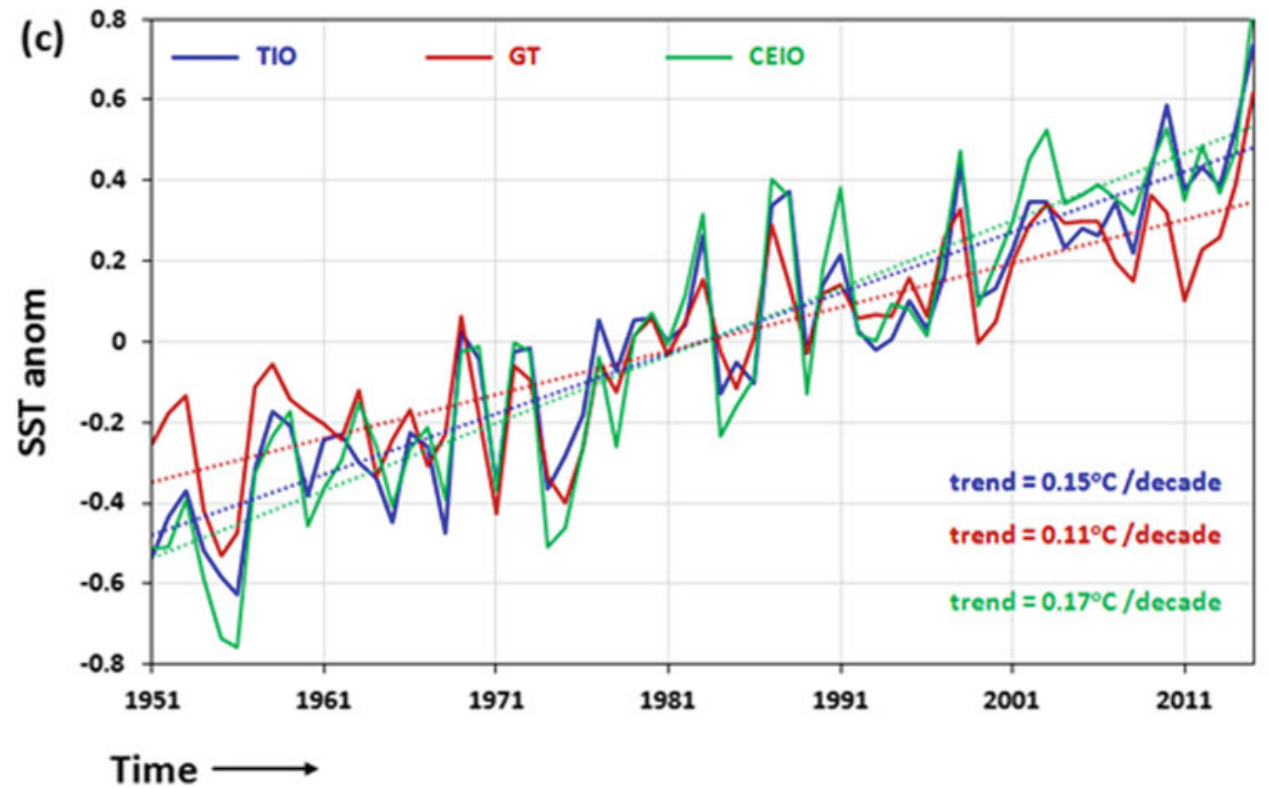

Fig. 10.1 SST trend $\left({ }^{\circ} \mathrm{C} /\right.$ decade $)$ from: a observed Extended Reconstructed Sea Surface Temperature, version 4 (ERSST v4) during 19512015, b CMIP5 historical simulations for 1976-2005 and c Time series of SST anomalies (solid lines) and their linear trends $\left({ }^{\circ} \mathrm{C} /\right.$ decade; dotted

during $1951-2015$ is $0.7{ }^{\circ} \mathrm{C}\left(0.11{ }^{\circ} \mathrm{C} /\right.$ decade $)$, while the TIO SST has risen by about $1.0^{\circ} \mathrm{C}$ on average $\left(0.15^{\circ}\right.$ C/decade) (high confidence) (Fig. 10.1). A 138-year (18702007) monthly observed SST time series averaged along the ship track extending from the Gulf of Aden through the Malacca Strait also reveals a warming of $1.4{ }^{\circ} \mathrm{C}$ during the line) over the tropical Indian Ocean (TIO, blue), central equatorial Indian Ocean (CEIO, $60{ }^{\circ} \mathrm{E}: 90{ }^{\circ} \mathrm{E} ; 10{ }^{\circ} \mathrm{S}: 10{ }^{\circ} \mathrm{N}$, green) and global tropics $\left(\mathrm{GT}, 0^{\circ}: 360^{\circ} ; 30^{\circ} \mathrm{S}: 30^{\circ} \mathrm{N}\right.$, red)

entire period (Chowdary et al. 2012). Coherently, historical simulations by climate models participating in the Coupled Model Inter-comparison Project (CMIP5), with $\mathrm{CO}_{2}$ forcing at observed rates, show warming trends of $0.1-0.18{ }^{\circ} \mathrm{C}$ per decade during 1976-2005 (Fig. 10.1b), with maximum warming trends over the northern Arabian Sea. 
Warming in the TIO has been basin-wide but spatially non-uniform, with the largest increasing trends seen in the central equatorial Indian Ocean and lowest warming trends off the Sumatra and Java coasts. While long-term warming (1900-2015) is maximum over the western Indian Ocean (Roxy et al. 2014), warming in recent decades is prominent over the central equatorial and subtropical south Indian Ocean (Fig. 10.1a). SST warming trends during the recent period (2000-2013) also exhibit an interhemispheric difference, with relatively weak warming to the north of $10^{\circ} \mathrm{S}$ and accelerated warming to the south of $10^{\circ} \mathrm{S}$ (Dong and McPhaden 2016).

\subsubsection{Attribution of SST Trends to Anthropogenic Emissions}

The observed surface warming over the Indian Ocean has been linked to natural and anthropogenic causes. Climate model simulations show that over $90 \%$ of the SST trend since the 1950s is very likely due to increased anthropogenic emissions (Du and Xie 2008; Dong and Zhou 2014; Dong et al. 2014), while the remaining is due to internal variability (Dong et al. 2014). Among the anthropogenic causes, change in radiative forcing due to the increased greenhouse gas concentrations is the major factor ( $\mathrm{Du}$ and Xie 2008). Over recent decades, increasing atmospheric pollutants, known as aerosols, have likely dampened the greenhouse gas forced warming of the Indian Ocean (Dong and Zhou 2014).

Changes in the tropical circulation, ocean-atmospheric interaction and dynamics play a role in the observed distribution of the warmer waters in the Indian Ocean. Redistribution of heat from the Pacific Ocean via the Walker circulation (Roxy et al. 2014) and the ITF (Dong and McPhaden 2016) is one of the reasons for the observed patterns of warming in the Indian Ocean. Other than the ITF, Indian Ocean may also be receiving a warming signal via the deep meridional overturning circulation, and from the Southern Ocean (Gille 2002). Contrary to expectation, there is a negative trend in the net heat flux despite the warming trend in the Indian Ocean SSTs (Rahul and Gnanaseelan 2013). This suggests that local ocean dynamics and ocean-atmosphere interaction also have a major role in the observed warming pattern in the Indian Ocean (Lau and Nath 2000; Du et al. 2009; Rahul and Gnanaseelan 2016; Pratik et al. 2019; Rao et al. 2012). The period 2000-2013 witnessed strong warming in the southern Indian Ocean south of $10^{\circ} \mathrm{S}$ inducing a north-south SST gradient. This interhemispheric gradient is forced primarily by an increased ITF, from the Pacific into the Indian Ocean, induced by stronger Pacific trade winds (Dong and McPhaden 2016; Lee et al 2015).

\subsubsection{Future Projections of SST Warming}

Future projections using CMIP5 simulations clearly show SST warming in the Indian Ocean with increasing anthropogenic emissions (high confidence). However, SST warming is projected to be non-uniform with regional variations in the Arabian Sea and the Bay of Bengal. Most models project a higher SST warming in the Arabian Sea than the Bay of Bengal. This is consistent with the changes that have been observed in the Indian Ocean in the last several decades (Zhao and Zhang 2016).

Changes in SSTs projected for the end of the twenty-first century show regional and seasonal variability (Cai et al. 2013). The ensemble mean of CMIP5 RCP scenarios indicates stronger warming in the north-western Indian Ocean and weaker warming off the Sumatra and Java coasts (Zheng and Xie 2009). The CMIP5 RCP scenarios for the period 2040-2069 and 2070-2099 are shown in Fig. 10.2, where the stronger warming in the north-western Indian Ocean and weaker warming in the south-eastern Indian Ocean south of $15^{\circ} \mathrm{S}$ with respect to the base period of 1976-2005 are evident, and consistent with Zheng and Xie (2009). Patterns of warming are similar in both the RCP4.5 and RCP8.5 scenarios, although the magnitude of warming is much larger in the latter scenario (Fig. 10.2). RCP4.5 projects a warming rate of $0.13{ }^{\circ} \mathrm{C} / \mathrm{dec}$ ade in the TIO (Fig. 10.2e), similar to the current rate of warming (Fig. 10.1c). Meanwhile, RCP8.5 indicates an accelerated warming at the rate of $0.35{ }^{\circ} \mathrm{C} /$ decade. CMIP5 (the ensemble mean) projected SST rise in the TIO in the near and far future for both the RCP4.5 and RCP8.5 scenarios are tabulated in Table 10.1.

The strong SST warming trend in the north-west basin accompanied by an increase in precipitation and weak SST warming trend in the south-east basin accompanied by decrease in precipitation drive strong surface easterly wind anomalies along the equatorial Indian Ocean ( $\mathrm{Li}$ et al. 2016). Along with the east-west gradient in SST and precipitation under global warming scenarios, the thermocline in the east equatorial Indian Ocean also shoals (a favourable condition for the formation of IOD) as a result of a weakened Indian Ocean Walker cell and easterly wind change along the equator (Zheng and Xie 2009). The shoaling of the thermocline then strengthens the thermocline feedback in this region. Such a pattern of SST, precipitation and thermocline feedback would result in more frequent occurrences of extreme positive IOD (pIOD) events in the future, from one event every 17.3 years over the twentieth century to one event every 6.3 years by the end of twenty-first century (low confidence) (Cai et al. 2014). This suggests increased risks of climate and weather extremes in regions impacted by extreme pIOD events. 
Fig. 10.2 CMIP5 projected SST change $\left({ }^{\circ} \mathrm{C}\right)$ in a RCP4.5 for 2040-2069, b RCP4.5 for 20702099, c RCP8.5 for 2040-2069 and d RCP8.5 for 2070-2099, with respect to the reference period 1976-2005. e Time series of projected SST anomalies with the trends $\left({ }^{\circ} \mathrm{C} / \mathrm{decade}\right)$ over the tropical Indian Ocean, in RCP4.5 (blue) and RCP8.5 (red) scenarios for 2040-2099
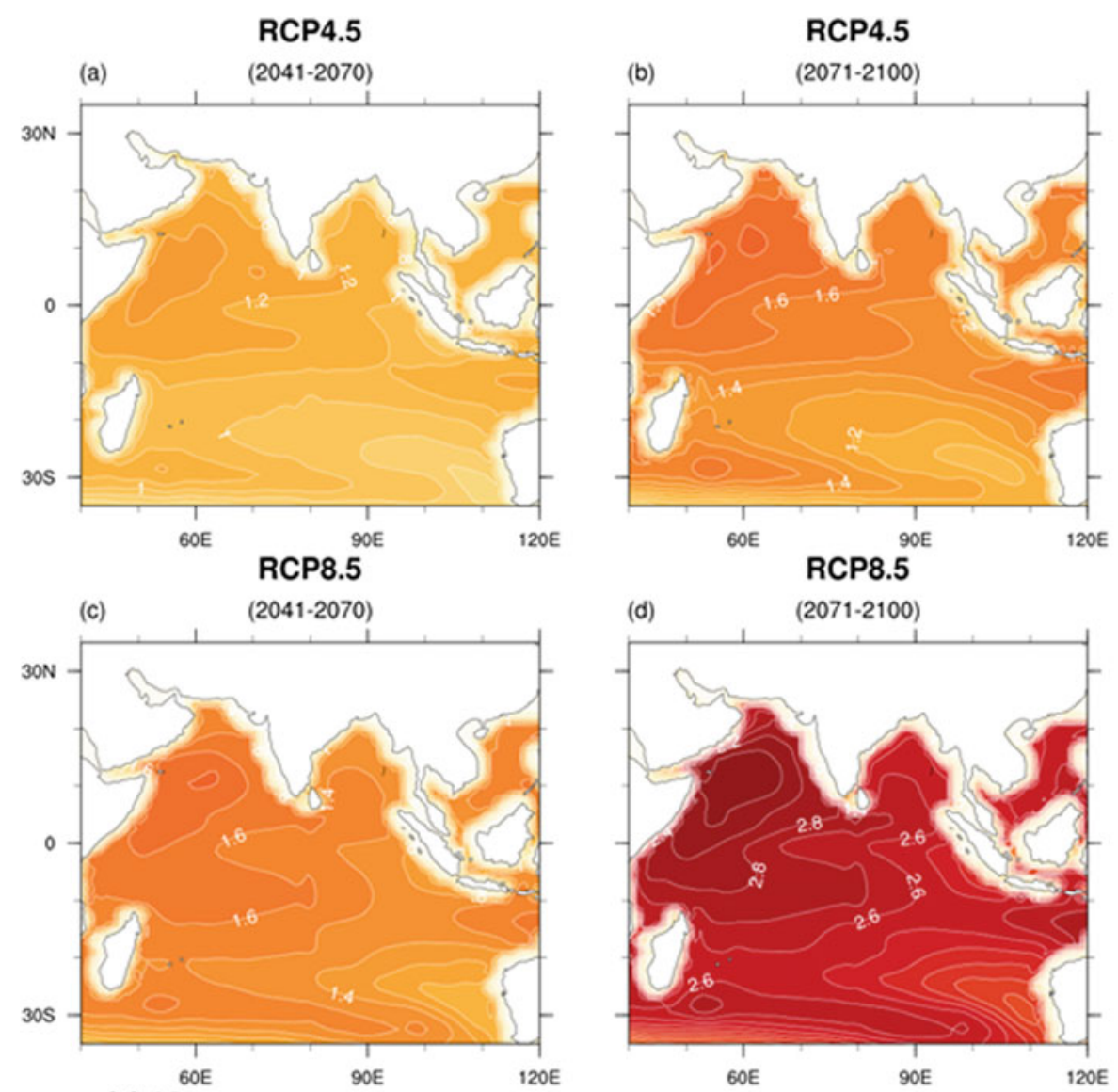

(b)

RCP4.5

(2071-2100)

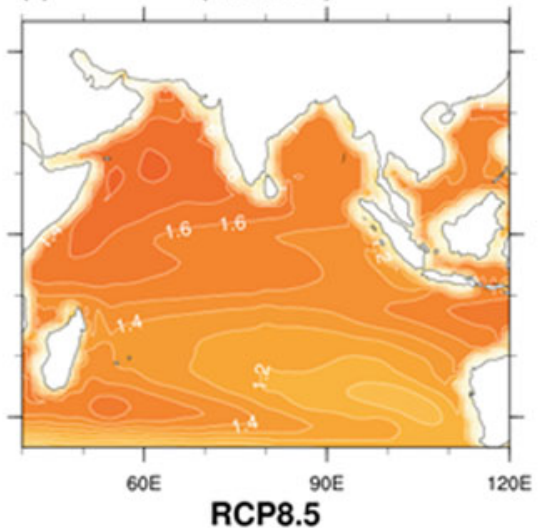

3

2.8

2.6

2.4

2.2

2

1.8

1.6

1.4

1.2

1

$-0.8$

0.6

0.4

0.2

0

Table 10.1 CMIP5 (ensemble mean) projected SST rise $\left({ }^{\circ} \mathrm{C}\right)$ averaged over the tropical Indian Ocean basin $\left(40{ }^{\circ} \mathrm{E}: 115^{\circ} \mathrm{E}, 30^{\circ} \mathrm{S}: 30{ }^{\circ} \mathrm{N}\right)$ in the near future (2040-2069) and far future (2070-2099) in the RCP4.5 and RCP8.5 scenarios w.r.t. the reference period 1976-2005

\begin{tabular}{l|l|l}
\hline Scenario & Near future & Far future \\
\hline RCP4.5 & $1.2^{\circ} \mathrm{C}\left( \pm 0.29^{\circ} \mathrm{C}\right)$ & $1.6^{\circ} \mathrm{C}\left( \pm 0.40{ }^{\circ} \mathrm{C}\right)$ \\
\hline RCP8.5 & $1.6{ }^{\circ} \mathrm{C}\left( \pm 0.55^{\circ} \mathrm{C}\right)$ & $2.7^{\circ} \mathrm{C}\left( \pm 0.64{ }^{\circ} \mathrm{C}\right)$ \\
\hline
\end{tabular}


Fig. 10.3 Time series of heat content anomaly of the $0-700 \mathrm{~m}$ (in $10^{22}$ Joules) for a Global Ocean, b Tropical Indian Ocean (blue) and North Indian Ocean (yellow). Dotted lines denote the respective 1955-2015 linear trends. Green dashed curve denotes the $\mathrm{OHC}$ anomaly for the 0-2000 m from 2005 to 2015. Spatial OHC anomaly $(0-700 \mathrm{~m})$ trends (in $10^{22}$ Joules/decade) are shown in (c). Data used is from NOAA's National Centers for Environmental Information (NCEI) (Levitus et al. 2009)
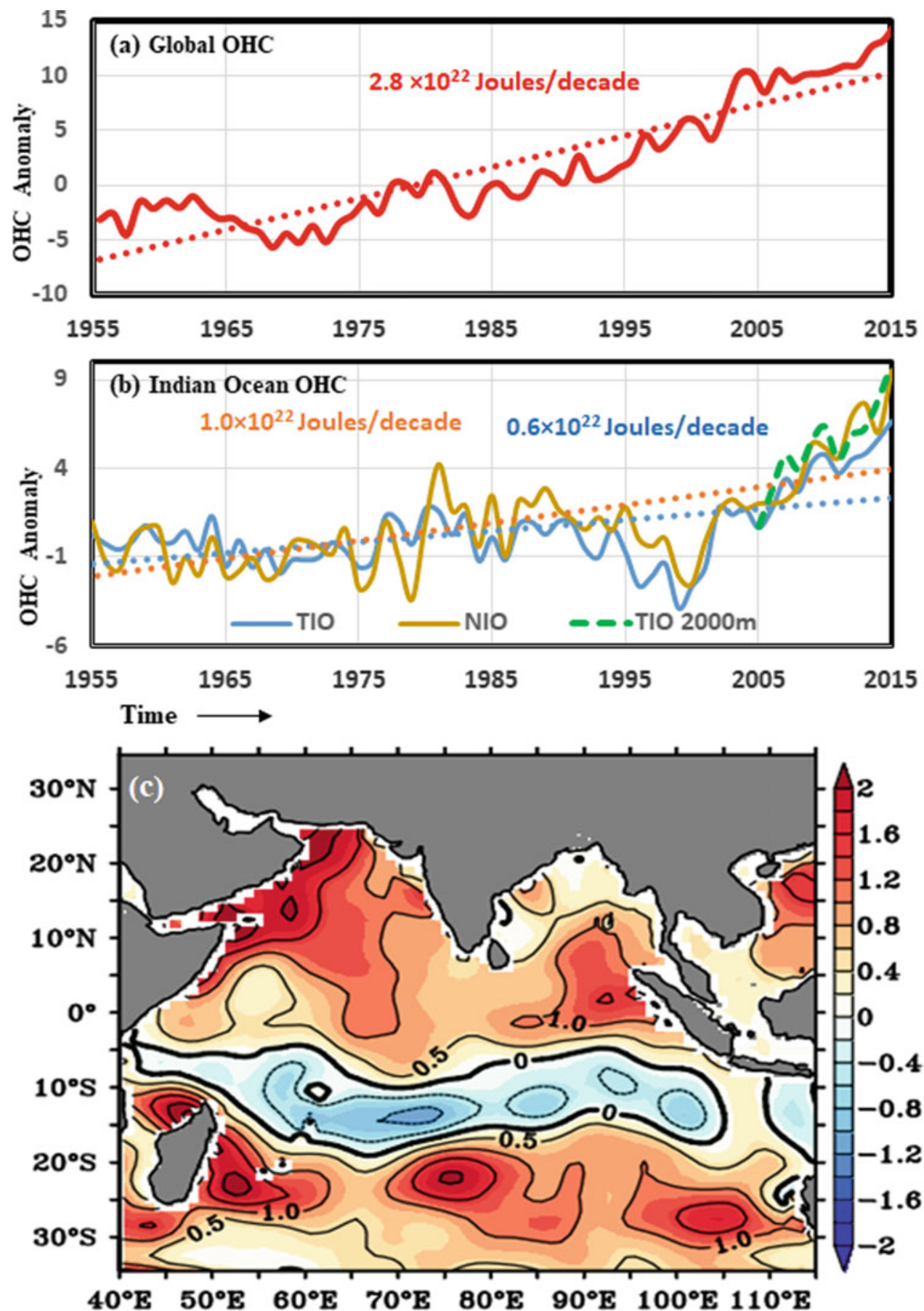

\subsection{Changes in Ocean Heat Content}

Contemporary global warming is driven by the additional heat trapped by greenhouse gases (GHGs) due to the Earth's energy imbalance between the energy absorbed and emitted. More than $90 \%$ of this additional heat is stored in the ocean, increasing ocean heat content $(\mathrm{OHC})$, while the residual heat is manifested in the form of melting of both land and sea ice, and in warming of the atmosphere and land surface. This makes it critical to monitor changes in $\mathrm{OHC}$ in order to understand the rate and extent of global warming (Von Schuckmann et al. 2014). The ocean's interior is more sensitive to small external forcing than the global surface ocean because it is highly sensitive to heat exchange in the high-latitudes (e.g. Rosenthal et al. 2017). Monitoring regional variations in $\mathrm{OHC}$ are also important for understanding climate variability and change (Allison et al. 2019). 
OHC changes also contribute substantially to sea-level rise, changes in ocean circulation, and energy transfer between ocean and atmosphere, making it a vital task to estimate and study historical $\mathrm{OHC}$. Increases in $\mathrm{OHC}$ in the recent past have been attributed to the increase in greenhouse gases in earth's atmosphere (e.g. Levitus et al. 2001 and Barnett et al. 2001, 2005). The primary impacts of an increase in OHC are its effects on marine biodiversity and the melting of glaciers in the regions like Greenland and Antarctica. Other consequences of $\mathrm{OHC}$ rise include declining ocean oxygen (Schmidtko et al. 2017), bleaching and death of corals (Hughes et al. 2018), ice shelves directly through bottom heating, exacerbating marine heat waves (Oliver et al. 2018), and altered impacts of natural variability such as ENSO, IOD and Pacific Decadal Oscillation (PDO; e.g. Fasullo et al. 2018). Over long time periods the ocean's interior acts like a capacitor and builds up large heat anomalies. These persisting large-scale $\mathrm{OHC}$ anomalies are a source of ocean climate predictability from seasonal-to-decadal timescales (e.g. Smith and Murphy 2007).

\subsubsection{Trends and Variability of Indian Ocean Heat Content}

Upper OHC exhibits an increasing trend in the Indian Ocean since the 1950s (high confidence, Levitus et al. 2009; Xue et al. 2012; Han et al. 2014). The global OHC700 has risen at a rate of $2.8 \times 10^{22}$ Joules per decade over the period 1955-2015 (Fig. 10.3a). Over the same period, the rate of rise in $\mathrm{OHC} 700$ in the tropical $\left(30{ }^{\circ} \mathrm{S}\right.$ to $30^{\circ} \mathrm{N}$ and $40{ }^{\circ} \mathrm{E}$ to $\left.115^{\circ} \mathrm{E}\right)$ and north $\left(5^{\circ} \mathrm{N}\right.$ to $30{ }^{\circ} \mathrm{N}$ and $40{ }^{\circ} \mathrm{E}$ to $\left.100{ }^{\circ} \mathrm{E}\right)$ Indian Ocean basins were more muted at $0.62 \times 10^{22}$ Joules per decade and $1.0 \times 10^{22}$ Joules per decade, respectively (Fig. 10.3b). In other words, there was greater net heat content gain in the north Indian Ocean (NIO) than the TIO over 1955-2015 despite being a smaller basin in areal extent.

It is important to note that since the year 2000 both the $\mathrm{TIO}$ and NIO have experienced a steep rise in OHC (Cheng et al. 2017), which is absent in the global OHC signal (Fig. 10.3a, b). This abrupt increase of OHC in TIO has accounted for more than $70 \%$ of the global ocean heat gain in the upper $700 \mathrm{~m}$ during the same period (e.g. Lee et al. 2015), despite of representing only about $15 \%$ of the global ocean area. It is very likely that a significant portion of the heat due to greenhouse warming now resides in the upper $700 \mathrm{~m}$ of the Indian Ocean. Given the fact that the OHC700 in the Indian Ocean did not increase significantly during 19712000 , the rapid increase during the recent period is striking.

In addition, higher variability in the TIO and NIO upper $\mathrm{OHC}$ compared to the global $\mathrm{OHC}$ is evident from Fig. 10.3. Changes in OHC700 in the NIO from 1955 to 2015 (Fig. 10.3c) show wide spatial variations with warming in the Arabian Sea, Bay of Bengal, equatorial Indian Ocean and in the region south of $20^{\circ} \mathrm{S}$ (Fig. 10.3c) (e.g. Nagamani et al. 2016; Anandh et al. 2018), but a zonally extended cooling from $20^{\circ} \mathrm{S}$ to $5^{\circ} \mathrm{S}$. Trends in TIO OHC2000 (ocean heat content in the upper $2000 \mathrm{~m}$ ) during 2005-2015 are similar to that of OHC700 (Fig. 10.3b).

There are significant differences in the recent OHC700 trends between the major ocean basins, particularly the Pacific and Indian Oceans. Despite of large natural variability in $\mathrm{OHC} 700$, increasing trends due to anthropogenic influence are evident (high confidence). The abrupt increase in the OHC700 during 2003-2012 was not due to surface heating, but due almost entirely to horizontal heat convergence in the form of an enhanced ITF (Lee et al. 2015). This Indian Ocean OHC increase corresponds to a concurrent Pacific Ocean $\mathrm{OHC}$ decrease in the 0-100 m, suggesting a transfer of heat from Pacific Ocean to Indian Ocean (Liu et al. 2016). The net surface heat flux into the Pacific Ocean increased greatly during 20032012, consistent with the La Niña-like condition across the Pacific Ocean. However, the anomalous surface heat uptake was completely masked by horizontal heat divergence in the tropical Pacific, which was mainly traced to the increased heat transport to the Indian Ocean. This has, in fact, inhibited the increase in tropical Pacific OHC700, which instead shows a slight decrease during this period.

Among the global oceans, the ensemble-mean trends for the 700-6000 m layer show the largest increasing trends in the North Atlantic sub-polar gyre, north Indian Ocean and Southern Ocean (e.g. Palmer et al. 2017). As there are fewer observations available in the Indian Ocean between 3000 and $5000 \mathrm{~m}$ compared to the other oceans, deep OHC estimates in the Indian Ocean, particularly in the north-western part, are relatively less accurate (Purkey and Johnson 2010). Although the Atlantic and Indian oceans contributed to the global $\mathrm{OHC}$ increase at $3500 \mathrm{~m}$ depth, the $\mathrm{OHC}$ increases in these two basins have been weak below $4000 \mathrm{~m}$ during the past two decades. The smaller contribution of the Indian Ocean to the global $\mathrm{OHC}$ increase might be due to the smaller bottom layer volume of the Indian Ocean than that of the Pacific Ocean (e.g. Kouketsu et al. 2011).

\subsubsection{Multidecadal Variability of the Indian Ocean Heat Content}

The observed upper OHC of the Indian Ocean reveals significant decadal variations (Han et al. 2014; Mohapatra et al. 2020). Model experiments suggest that the observed multidecadal trends in OHC are partially associated with anthropogenic forcing. The observed decadal variability in the basin-wide distribution of sea level and thermal structure in the Indian Ocean results primarily from forcing by Indian Ocean winds (Deepa et al. 2019; Srinivasu et al. 2017), with 
a significant contribution from the ITF transport to the interior of the south Indian Ocean after 1990 (Han et al. 2014). For the Pacific and Indian Oceans, decadal shifts are primarily observed in the upper $350 \mathrm{~m}$, likely due to shallow subtropical circulation, leading to an abrupt increase of $\mathrm{OHC}$ in the Indian Ocean carried by the ITF from the Pacific Ocean over the last decade (Cheng et al. 2017). During the slowdown in Pacific SST warming, there was anomalous warming in the Indian Ocean and an accelerated OHC rise below $50 \mathrm{~m}$, which is associated with a La Niña-like climate shift, and an enhanced heat transport of the ITF (Liu et al. 2016). Transmission of the multidecadal signal occurs via an oceanic pathway through the ITF and is manifested across the Indian Ocean centred along $12^{\circ} \mathrm{S}$ as westwardpropagating Rossby waves modulating the thermocline and subsurface heat content variations (Rahul and Gnanaseelan, 2016; Deepa et al. 2019). Changes in Pacific wind forcing in recent decades and associated rapid increases in Indian Ocean subsurface heat content can thus affect the basin's leading mode of variability (Ummenhofer et al. 2017). Jin et al (2018) argued that the western Indian Ocean subsurface heat content is influenced by Interdecadal Pacific oscillation (IPO) through wind driven Ekman pumping via the atmospheric bridge, whereas the eastern Indian Ocean is largely affected through the oceanic pathway via ITF. The recent negative phase of IPO (1998-2012) enhanced the Pacific easterlies, which eventually led to export of anomalous heat from the Pacific towards the Indian Ocean (Gastineau et al 2018). The OHC300-based definition of PDO takes into account variations throughout the upper ocean and is better suited to capture various characteristics of PDO variability (Kumar and Wen 2016). Based on multiple observational datasets, ocean reanalysis products and an ocean model simulation, Li et al. (2018) reported the presence of prominent multidecadal variations in the Indian Ocean OHC400. They suggested that the upper Indian Ocean first experienced a heat content increase at the rate of $5.9 \pm 2.5 \times 10^{21} \mathrm{~J} \mathrm{decade}^{-1}$ during $1965-79$, followed by a decrease at the rate of $-5.2 \pm 2.5 \times 10^{21} \mathrm{~J} \mathrm{decade}^{-1}$ during 1980-96, and subsequently an enhanced rate of increase of $13.6 \pm 1.1 \times 10^{21} \mathrm{~J} \mathrm{decade}^{-1}$ from 2000 to 2014. This suggests that the Indian Ocean OHC underwent tremendous decadal variations which might continue into the future. CMIP5 simulations have limited skill in capturing decadal variability in upper $\mathrm{OHC}$ during the past 45 years (Collins et al. 2013; Cheng et al. 2015).

\subsubsection{Future Projections of Indian Ocean Heat Content}

Monitoring and understanding $\mathrm{OHC}$ change and the role of circulation in shaping the patterns of increase remain key to predicting global and regional climate change, and sea-level rise (Zanna et al. 2019). Under the low-to-medium (RCP4.5) emissions scenario, half of the energy taken up by the ocean by the end of the twenty-first century will be in the uppermost $700 \mathrm{~m}$, and $85 \%$ will be in the uppermost $2000 \mathrm{~m}$ (low confidence). Future changes in wind and air-sea fluxes, and ocean transport, likely to have serious implications for regional sea-level rise and coastal flood risk. Additionally, the spatial patterns of $\mathrm{OHC}$ change under global warming contribute to the regional sea-level projections (e.g. Slangen et al 2014). There is a large spread among CMIP5 models in projections of future changes in $\mathrm{OHC}$, suggesting an urgent need for further refinement (Cheng et al 2016; Allison et al. 2019).

\subsection{Impacts of Indian Ocean Warming \\ 10.4.1 Consequences of Indian Ocean Warming on Regional Climate}

Rapid warming of the Indian Ocean during 1950-2015, along with substantial changes in land use and anthropogenic aerosols have altered the Indian summer monsoon (Singh et al. 2019, Chaps. 3 and 6). During 1950-2015, there has been a significant decline in the summer monsoon rainfall over central India and parts of north India due to a reduction in the tropospheric thermal contrast that is associated with the rapid warming of the Indian Ocean (Mishra et al. 2012; Saha et al. 2014; Roxy et al. 2016). At the same time, rapid warming in the Arabian Sea has resulted in a rise in widespread extreme rains over Western Ghats and central India, since warming induces increased fluctuations in the monsoon winds, with ensuing episodes of enhanced moisture transport from the Arabian Sea towards the Indian subcontinent (Roxy et al. 2017). Indian Ocean warming is also found to reduce rainfall over India during the onset phase and increase it during the withdrawal phase (Chakravorty et al. 2016).

In terms of tropical cyclones, the Bay of Bengal region witnesses more than $80 \%$ of the global fatalities associated with tropical cyclones, while only accounting for $5 \%$ of these storms globally (Beal et al. 2019). Since tropical cyclones primarily draw their energy from evaporation at the ocean surface, SST and OHC strongly constrain cyclone intensity (Rajeevan et al. 2013). Global warming appears to have increased the intensity of tropical cyclones during the post-monsoon period in the Bay of Bengal (Chap. 8) and the pre-monsoon period in the Arabian Sea. For example, Cyclone Nilofar in 2014 was the first severe tropical cyclone to be recorded in the Arabian Sea in the post-monsoon season. Though the cyclone did not make landfall, it produced heavy rainfall along the western coast of India. Future 
projections suggest a likely increase in the number of extremely severe tropical cyclones in response to Indian Ocean warming, particularly in the Arabian Sea, while changes in frequency remain uncertain (Chap. 8).

Indian Ocean SSTs have a role in regulating the surface air temperatures over the Indian subcontinent (Chowdary et al. 2014). Associated with the basin-wide warming and frequent El Niños, the frequency and duration of heat waves have increased over the Indian subcontinent (Rohini et al. 2016). Rising ocean temperatures have also resulted in instances of marine heat waves in the Indian Ocean. Marine heat waves are similar to heat waves over the land, with periods of extremely high ocean temperatures that persist for days to months (Collins et al. 2019). Recent marine heat waves, including the one in 2016 that co-occurred with an extreme El Niño event of 2015-16, resulted in mass bleaching of coral reefs and adversely impacted aquaculture industries along the Indian Ocean rim countries (Collins et al. 2019). Satellite observations reveal that the intensity of marine heat waves have increased and that they have very likely doubled in frequency over 1982-2016. Climate projections indicate that at the high emissions RCP 8.5 GHG scenario, a one-in-100-day marine heat wave event (with pre-industrial $\mathrm{CO}_{2}$ levels) is very likely to become a one-in-four-day event by 2031-2050 and a one-in-two-day event by 2081-2100 (Collins et al. 2019).

The impact of Indian Ocean warming is reflected in the sea-level changes, as thermal variations have dominated these changes in recent decades (Chap. 9). The largest sea-level changes were observed along the northern and eastern coasts of the Bay of Bengal (Chap. 9). Tide gauge data corroborates the increasing sea level among the coastal regions of the Indian Ocean, such as Mumbai, Kochi, Visakhapatnam on the Indian coast and Durban, Fremantle, Port Hedland on the Australian coast. The consistent increase in sea level is attributed to the thermal expansion of sea water, due to a basin-wide surface warming in the Indian Ocean. Besides, the observed changes in the wind circulation in the Indian Ocean has modulated the ocean heat transport, and distributed the heat across the basin, resulting in a large thermosteric response in the sea level (Chap. 9).

Beyond the regional climate, Indian Ocean warming has global and remote impacts also. The Indian Ocean has contributed to more than $21 \%$ of the global oceanic heat uptake over the last two decades and contributed strongly to the temporary slowdown in global warming during 19982013 (Lee et al. 2015; Cheng et al. 2017). Climate model experiments indicate that the rapid warming of the Indian Ocean is strengthening the Atlantic meridional overturning circulation (Hu and Fedorov 2019; Cherchi 2019). The basin-wide warming could modulate the Pacific climate, affect the North Atlantic oscillation and enhance the positive
Southern Annular Mode, and may cause West Sahel and Mediterranean droughts (Beal et al. 2019). Atmospheric blocking triggered by tropical convection in the Indian and Pacific oceans can cause persistent anticyclonic circulation that not only leads to severe drought but also generates marine heat waves in the adjacent ocean. Warming in the Indian Ocean and associated deep convection is found to trigger droughts in South America and marine heat waves in the adjoining South Atlantic (Rodrigues et al. 2019). A strong negative IOD event in 2016 strongly impacted East African rainfall, with some regions recording below $50 \%$ of normal rainfall, leading to devastating drought, food insecurity and unsafe drinking water for over 15 million people in Somalia, Ethiopia and Kenya (Collins et al. 2019).

\subsubsection{Consequences of Indian Ocean Warming on Ocean Biogeochemistry}

The biogeochemical properties of the Indian Ocean are distinct from other ocean basins for mainly two reasons - the land boundary in the north due to Indian subcontinent and the large amplitude of seasonally reversing monsoon cycle. Climate driven physical fluctuations are expected to impact the marine ecosystem substantially by modifying the biotic and abiotic environments, which can lead to severe repercussions for the oceanic primary production. The warming of SSTs in the western Indian Ocean leads to increased stratification in the basin. Roxy et al. (2016) show a declining trend in marine phytoplankton in the western Indian Ocean (high confidence), by $30 \%$ in the observations during 1998-2013 and $20 \%$ in the CMIP5 simulations during 1950-2015 (medium confidence). This significant decline in phytoplankton is attributed to enhanced stratification of the oceanic water column as a result of rapid surface warming, thereby suppressing the mixing of nutrients from subsurface layers into the surface. Downward trends in primary production over the Indian Ocean can be detrimental to the marine food web and the fishing industry, especially the economically valuable tuna industry (Lee et al. 2005). However, careful gathering of in situ observations in the open ocean is needed to build a substantial understanding of the bio-physical interactions in the Indian Ocean.

Approximately $30 \%$ of the historical anthropogenic $\mathrm{CO}_{2}$ emissions have been absorbed by the oceans since the pre-industrial era (e.g. Canadell et al. 2007). The increasing oceanic uptake of $\mathrm{CO}_{2}$ has changed seawater chemistry and resulted in ocean acidification, with profound impacts on biological ecosystems in the upper ocean. Long-term increasing trends in ocean acidification, consistent with the increase in atmospheric $\mathrm{CO}_{2}$, are evident over the past several decades (Dore et al. 2009). 
Fig. 10.4 Projected changes in multiple stressor intensity in 2090-2099 relative to 1990-1999 under the RCP8.5 scenario. Red indicates where sea surface warming exceeds $+3.5^{\circ} \mathrm{C}$, hatched yellow indicates where subsurface (200-600 m) oxygen concentrations decrease by more than $20 \mu \mathrm{mol} / \mathrm{m}^{3}$ and hatched blue indicates where vertically integrated annual NPP decreases by more than $100 \mathrm{gC} / \mathrm{m}^{2}$. In addition, hatched orange indicates present-day simulated low-oxygen $\left(<50 \mathrm{mmol} / \mathrm{m}^{3}\right)$ in the subsurface waters Figure adapted from Bopp et al. (2013)

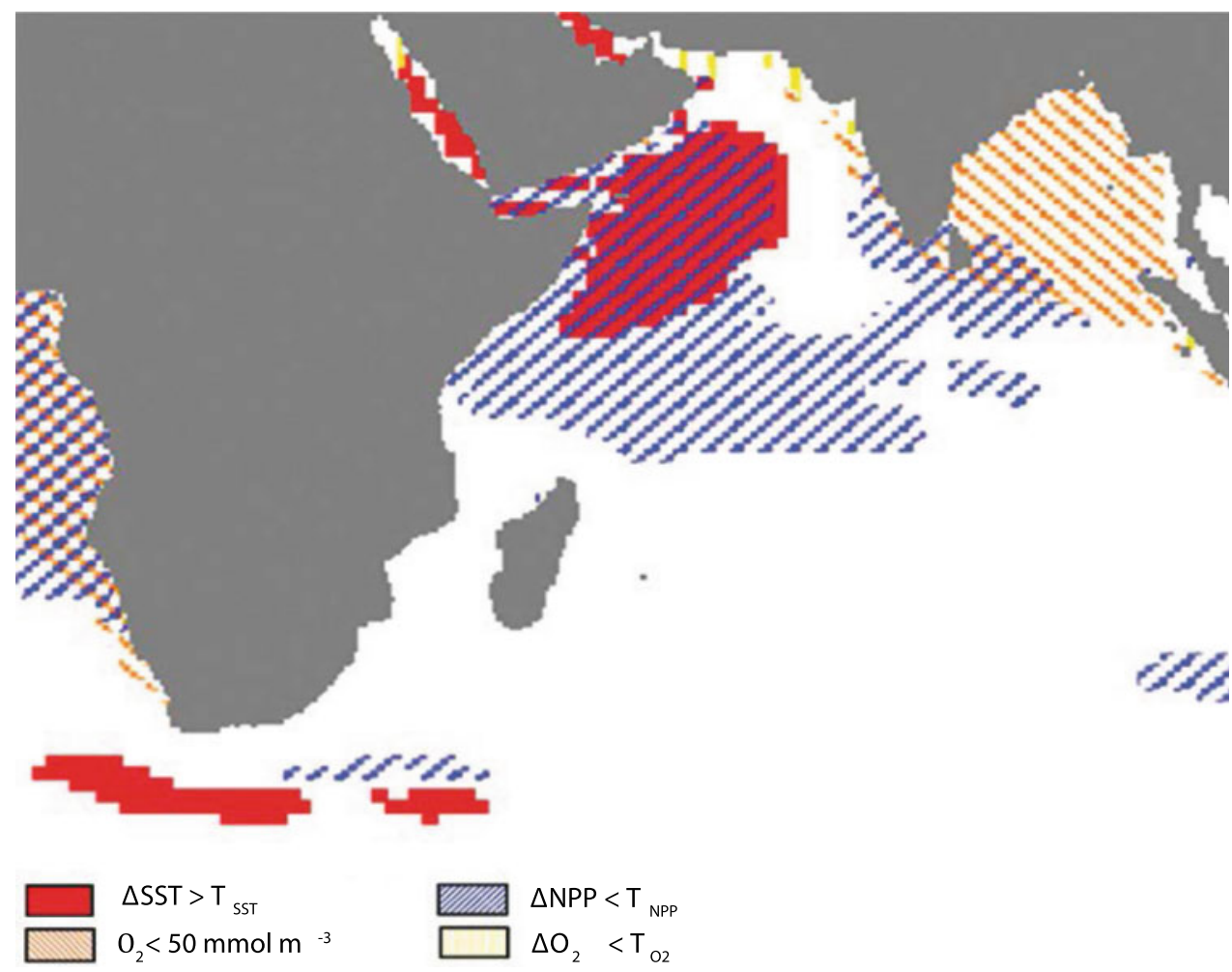

Recent work by Sreeush et al. (2019a) has found that the Indian Ocean is acidifying due to the accumulation of anthropogenic $\mathrm{CO}_{2}$ from the atmosphere, and this storage of anthropogenic carbon in the Indian Ocean is comparable (after normalizing for the size of the basins) with the other major oceans (Sabine et al. 2004). Surface ocean pH over the Indian Ocean has declined by about 0.1 unit (current mean is 8.1) relative to pre-industrial levels and is larger over the western Indian Ocean (e.g. Sreeush et al. 2019a). This increase in ocean acidity may be responsible for the functional collapse of reef building corals. The western Arabian Sea has undergone more rapid acidification than the rest of the TIO basin due to strong upwelling in this region drawing up anthropogenic $\mathrm{CO}_{2}$ embedded in the deeper ocean. Moreover, SST warming also accelerates acidification due to the endothermic nature of $\mathrm{CO}_{2}$ dissolution in water. An ocean biogeochemical model-based simulations from 1960 to 2009 show that western Arabian Sea has acidified by $108 \%$ due to dissolved inorganic carbon, $-36 \%$ due to buffering due to alkalinity, $16 \%$ due to SST warming, $6 \%$ due to salinity changes and remaining due to changes in other minor ions (Sreeush et al. 2019a). Considering that the western Arabian Sea is a highly productive zone of the Indian Ocean (Roxy et al. 2016), the role of SST warming in exacerbating acidification needs to be monitored carefully.

Dissolved $\mathrm{O}_{2}$ is a major determinant of the abundance and distribution of the marine habitat. The Indian Ocean

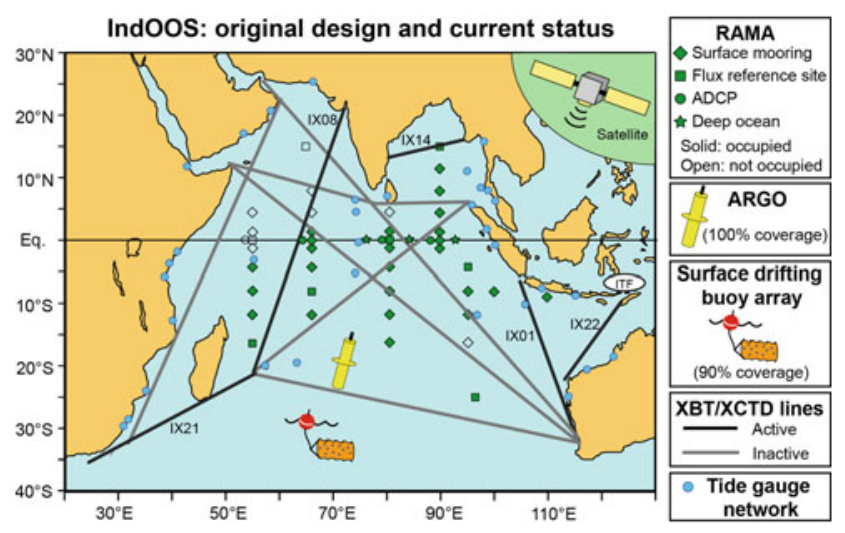

Fig. 10.5 Status of the Indian Ocean Observing System (IndOOS) in 2018. The sustained observing system in the Indian Ocean comprises of the Argo, RAMA, XBT/XCTD, surface drifting buoy and tide gauge networks. It is supported by satellite observations and the GO-SHIP program. The empty symbols indicate RAMA sites that were not implemented due to logistical constraints Source: Beal et al. 2019

contains one of the oceans' most pronounced oxygen minimum zones (OMZs) encompassing more than $50 \%$ of the area containing OMZs (e.g. Helly and Levin 2004). The tropical open ocean $\mathrm{O}_{2}$ concentration has decreased at a rate of $0.1-0.3 \mu \mathrm{mol} \mathrm{kg}{ }^{-1}$ year $^{-1}$ during the past five decades (Stramma et al. 2008). Long-term measurements over the TIO also show a pronounced decrease (at a rate of 20$30 \mathrm{~mol} \mathrm{~m}^{-2}$ per decade) in $\mathrm{O}_{2}$ concentration (Koslow et al. 


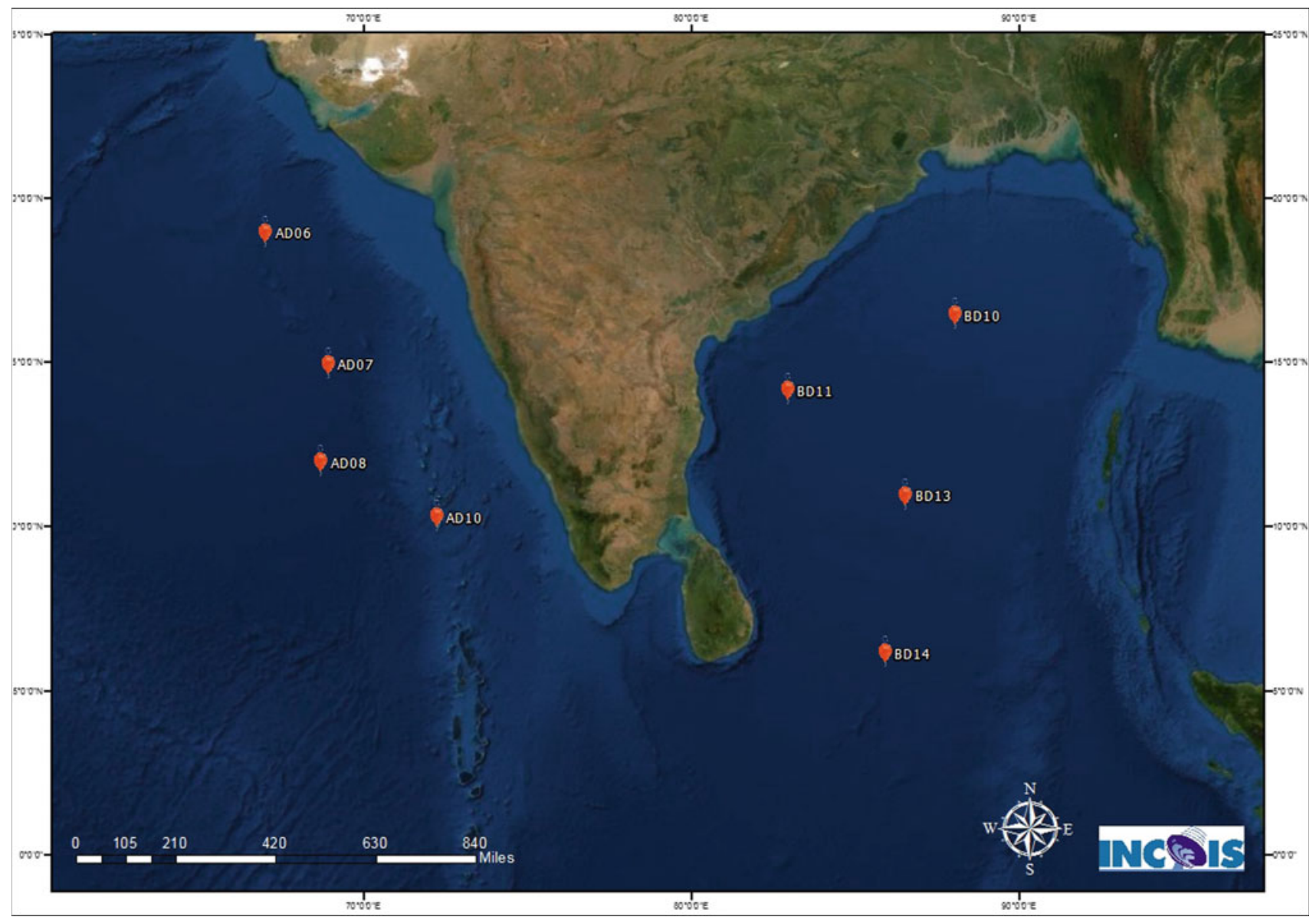

Fig. 10.6 Status of the OMNI moorings as on Oct 2019, installed by INCOIS/NIOT in the north Indian Ocean

2011). This oxygen decline is a result of warming-induced decline in oxygen solubility and reduced ventilation of deep ocean due to enhanced ocean surface stratification (Keeling et al. 2010).

Future projections based on the CMIP5 models indicate further warming of the Indian Ocean and a resultant decline in marine primary productivity (Fig. 10.4, Bopp et al. 2013). CMIP5 models also project a continuing decline in open-ocean surface $\mathrm{pH}$ from the current mean of $8.1-7.8$ by the end of the twenty-first century, as a response to the projected rise in $\mathrm{CO}_{2}$ emissions (Bopp et al. 2013). Most models project decreasing oxygen concentrations in the ocean by $1-7 \%$ from present-day concentrations by 2100 , with global warming (Keeling et al. 2010; Bopp et al. 2013).

Interactions of rising temperatures, ocean acidification and oxygen minimum zones narrow thermal ranges and enhance sensitivity to temperature extremes in marine organisms ranging from corals to fish. These negative effects of increase in warming are projected to be most significant in developing nations in tropical regions (high confidence, IPCC AR5 2014). However, understanding the combined effect of both low $\mathrm{O}_{2}$ and low $\mathrm{pH}$ on marine ecosystems in the Indian Ocean demands more active research in the Indian Ocean.

\subsection{Knowledge Gaps}

Though we understand the extent and magnitude of the warming trend, we still do not have a clear understanding on the amount of heat entering and exiting the Indian Ocean through the various ocean-atmospheric pathways. One of the reasons is the inability to accurately perform a heat budget analysis, due to lack of long-term high frequency data over regions like the western Indian Ocean and the ITF (Fig. 10.5). This need to be resolved with a combination of Research Moored Array for African-Asian-Australian Monsoon Analysis and Prediction (RAMA) moorings and Argo buoys (and gliders where both do not function) which measure ocean data at various timescales. Also, though Argo floats can generally provide measurements up to a depth of $2000 \mathrm{~m}$, only $60 \%$ of the floats do so. Hence, the uncertainty in warming trends in the deeper ocean could be large, and need to be addressed. Sustained measurements of air-sea 
heat fluxes and their components are needed to address the uncertainties in SST trends (Beal et al. 2019).

The lack of sufficient observation from Indian Ocean for the upper ocean carbon cycle research is a lacuna at present. Surface ocean parameters such as ocean partial pressure of $\mathrm{CO}_{2}\left(\mathrm{pCO}_{2}\right)$ and nutrients such as $\mathrm{PO}_{4}$ and $\mathrm{NO}_{3}$ are worthy of observing because they can cascade through the ocean solubility and biological pumps to constrain the variables and parameters in the upper ocean carbon cycle yielding robust estimates of upper ocean carbon budget of the Indian Ocean (Sreeush et al. 2019b).

There is a mooring network in the northern Indian Ocean, Ocean Moored Buoy Network for northern Indian Ocean (OMNI), led by India that also records high resolution ocean and near-surface meteorological data (Fig. 10.6). The Ministry of Earth Sciences (MoES) of India announced in June 2018 that the data from OMNI outside the Indian EEZ would be made freely available at data standards similar to that of RAMA. A coordinated moored network combining RAMA and OMNI is a priority for successful monitoring of changes in the Indian Ocean and also for skilful forecasting.

Further, CMIP5 models fail to reproduce the observed pattern of SST warming in the Indian Ocean, and as a result they fail to represent the local and remote impact on the climate system in the models (Saha et al. 2014). Hence, it is necessary to accurately monitor changes over the Indian Ocean, and also improve the models to simulate these changes, for successful future projections of the regional climate.

\section{Box 10.1 Modes of climate variability in the} Indo-Pacific

El Niño Southern Oscillation (ENSO): ENSO is a coupled ocean-atmosphere mode of interannual variability with a periodicity of about 4-7 years. El Niño is the positive phase of ENSO, characterized by anomalous surface warming of eastern and central equatorial Pacific, lasting for several months. The negative phase with cooler (than normal) SST in the eastern equatorial Pacific is called La Niña. There are several indices to quantify the strength, nature and duration of El Niño based on the anomalous SST over different regions of eastern and central equatorial Pacific. The atmospheric counterpart to this interannual warming/cooling is known as southern oscillation, which is quantified as the anomalous sea-level pressure difference between Darwin and Tahiti. The southern oscillation index quantifies the intensity of Walker circulation and the ocean atmosphere coupling associated with El Niño and La Niña. El Niño is found to weaken the Indian summer monsoon and warm the
Indian Ocean basin, whereas La Niña strengthens the monsoon and cools the Indian Ocean basin. Different flavours of El Niño such as east Pacific (cold tongue) El Niño, central Pacific (warm pool) El Niño (or Modoki, Ashok et al. 2007) and their regional impacts are significant over the Indian landmass and Indian Ocean.

Pacific decadal oscillation (PDO): PDO is a decadal mode of variability in the north Pacific (north of $20^{\circ} \mathrm{N}$ ), with warm SST anomalies in the eastern and north Pacific and cold SST anomalies in the central north Pacific during the positive phase, and vice versa in the negative phase. In the equatorial Pacific, PDO imprints similar spatial structure as that of ENSO but with a longer time scale. When PDO and ENSO are in the same phase, the impact of ENSO is amplified. Interdecadal Pacific oscillation (IPO) is similar to PDO but has a wider spatial structure covering both southern hemisphere and northern hemisphere, with the pattern of warming and cooling in the north Pacific similar to that of PDO. The typical cycle of a PDO or IPO is about 15-30 years, but in some period, one phase itself may last more than 20-30 years.

Indian Ocean basin mode (IOBM) and Indian Ocean Dipole (IOD): TIO is characterized by several modes of climate variability such as the Indian Ocean basin mode (IOBM, Klein et al. 1999; Xie et al. 2002; Chowdary and Gnanaseelan 2007), Indian Ocean Dipole (IOD, Saji et al. 1999; Webster et al. 1999), and subsurface mode (Sayantani and Gnanaseelan 2015). IOBM is mainly caused by ENSO forcing and the associated changes in the net heat flux. IOD is an ocean atmosphere coupled climate mode of variability (east west) in the tropical Indian Ocean, defined as the difference in SST anomalies of western $\left(50{ }^{\circ} \mathrm{E}\right.$ to $70^{\circ}$ $\mathrm{E} ; 10^{\circ} \mathrm{S}$ to $\left.10^{\circ} \mathrm{N}\right)$ and south-eastern $\left(90^{\circ} \mathrm{E}\right.$ to $110^{\circ} \mathrm{E}$; $10^{\circ} \mathrm{S}$ to equator) equatorial Indian Ocean (Saji et al 1999). In contrast to the SST variability, subsurface temperature (at thermocline) displays a north-south mode of variability. Generally, a positive IOD favours enhanced summer monsoon rainfall over the Indian subcontinent while negative IOD favours less rainfall. More details on the ENSO-IOD-monsoon interactions are given in Chapter 3, Box 3.2.

\subsection{Summary}

The ocean-atmospheric conditions in the Indian Ocean region strongly modulate the subcontinental climate. This chapter has assessed changes in the Indian Ocean in the 
recent past, as well as changes anticipated over the twenty-first century based on simulations by state-of-the-art global climate models.

The SST of the TIO has warmed by about $1{ }^{\circ} \mathrm{C}$ over the period 1951-2015, which is much higher than the global average SST rise of about $0.7{ }^{\circ} \mathrm{C}$ over the same period. Most of this temperature rise is attributed to anthropogenic emissions. Heat content in the upper Indian Ocean (OHC700) has also exhibited an increasing trend since the 1950s, with a notably abrupt rise after the year 2000. Observed declining trends in phytoplankton and oxygen concentrations in the TIO, attributed to SST warming, and the increasing acidification of the Indian Ocean due to excess $\mathrm{CO}_{2}$ uptake, have also likely impacted marine ecosystems in the western Indian Ocean.

Climate models project a rise in surface temperatures of the TIO by $1.2-1.6{ }^{\circ} \mathrm{C}$ and $1.6-2.7{ }^{\circ} \mathrm{C}$ in the near and far futures across GHG emissions scenarios (RCP4.5 and RCP8.5) relative to the reference period 1976-2005. Trends in other observed changes are also projected to continue with global warming.

Lack of sufficient observations in the western Indian Ocean and the Indonesian Through flow has hampered the understanding of changes in the heat budget of the Indian Ocean. Increasing the skill of Indian Ocean forecasts requires coordinated efforts in monitoring changes in the Indian Ocean at different time scales and at different depths. Efforts in these directions are already underway.

The central role of the Indian Ocean in modulating the regional climate implies that changes in this basin have serious implications for both the densely populated coastal regions around this basin, and for marine ecosystems. Hence, efforts towards detailed and continuous monitoring of ongoing changes and improving climate models are essential for developing effective adaptation and mitigation strategies to reduce risk due to climate change.

\section{References}

Allison LC, Roberts CD, Palmer MD, Hermanson L, Killick RE, Rayner NA, Smith DM, Andrews MB (2019) Towards quantifying uncertainty in ocean heat content changes using synthetic profiles. Environ Res Lett 14(8):084037

Ashok K, Behera SK, Rao SA, Weng H, Yamagata T (2007) El Niño Modoki and its possible teleconnection. J Geophys Res Oceans 112: C11007. https://doi.org/10.1029/2006JC003798

Anandh TS, Das BK, Kumar B, Kuttippurath J, Chakraborty A (2018) Analyses of the oceanic heat content during 1980-2014 and satellite-era cyclones over Bay of Bengal. Int J Climatol 38:56195632. https://doi.org/10.1002/joc.5767

Barnett TP, Pierce DW, Schnur R (2001) Detection of anthropogenic climate change in the world's oceans. Science 292:270-274. https:// doi.org/10.1126/science. 1058304
Barnett TP, Pierce DW, AchutaRao KM, Gleckler PJ, Santer BD, Gregory JM, Washington WM (2005) Penetration of human-induced warming into the world's oceans. Science 309:284-287. https://doi.org/10.1126/science.1112418

Beal LM, Vialard J, Roxy MK et al (2019) IndOOS-2: a roadmap to sustained observations of the Indian Ocean for 2020-2030. CLIVAR-4/2019. https://doi.org/10.36071/clivar.rp.4-1.2019

Bopp L, Resplandy L, Orr JC, Doney SC, Dunne JP, Gehlen M, Vichi M (2013) Multiple stressors of ocean ecosystems in the 21st century: projections with CMIP5 models. Biogeosciences 10 (10):6225-6245. https://doi.org/10.5194/bg-10-6225-2013

Cai W, Santoso A, Wang G et al (2014) Increased frequency of extreme Indian Ocean Dipole events due to greenhouse warming. Nature 510:254-258. https://doi.org/10.1038/nature13327

Cai W, Zheng X-T, Weller E et al (2013) Projected response of the Indian Ocean Dipole to greenhouse warming. Nat Geosci 6:9991007. https://doi.org/10.1038/ngeo2009

Canadell JG et al (2007) Contributions to accelerating atmospheric $\mathrm{CO}_{2}$ growth from economic activity, carbon intensity, and efficiency of natural sinks. Proc Natl Acad Sci USA 104:18866-18870

Chakravorty S, Gnanaseelan C, Pillai PA (2016) Combined influence of remote and local SST forcing on Indian Summer Monsoon Rainfall variability. Clim Dyn 47(9-10):2817-2831

Cheng LJ, Zhu J, Abraham J (2015) Global upper ocean heat content estimation: recent progress and the remaining challenges. Atmos Oceanic Sci Lett 8:333-338. https://doi.org/10.3878/ AOSL20150031

Cheng L, Trenberth KE, Palmer MD, Zhu J, Abraham JP (2016) Observed and simulated full-depth ocean heat-content changes for 1970-2005. Ocean Sci 12(4):925-935. https://doi.org/10.5194/os12-925-2016

Cheng L, Trenberth K, Fasullo J, Boyer T, Abraham J, Zhu J (2017) Improved estimates of ocean heat content from 1960 to 2015. Sci Adv 3:e1601545. https://doi.org/10.1126/sciadv.1601545

Cherchi A (2019) Connecting AMOC changes. Nat Clim Chang 9:729_ 730

Chowdary JS, Gnanaseelan C (2007) Basin-wide warming of the Indian Ocean during El Nino and Indian Ocean dipole years. Int J Climatol 27:1421-1438

Chowdary JS, John N, Gnanaseelan C (2014) Interannual variability of surface air-temperature over India: impact of ENSO and Indian Ocean Sea surface temperature. Int J Climatol 34(2):416-429

Chowdary JS, Xie SP, Tokinaga H, Okumura YM, Kubota H, Johnson N, Zheng XT (2012) Interdecadal variations in ENSO teleconnection to the Indo-western Pacific for 1870-2007. J Clim 25(5):1722-1744. https://doi.org/10.1175/JCLI-D-11-00070.1

Collins M, Knutti R, Arblaster J, Dufresne JL, Fichefet T, Friedlingstein P, Gao X, Gutowski WJ, Johns T, Krinner G, Shongwe M, Tebaldi C, Weaver AJ, Wehner M (2013) Long-term climate change: projections, commitments and irreversibility. In: Stocker TF, Qin D, Plattner GK, Tignor M, Allen SK, Boschung J, Nauels A, Xia Y, Bex V, Midgley PM (eds) Climate change 2013: the physical science basis. Contribution of working group I to the fifth assessment report of the intergovernmental panel on climate change. Cambridge University Press, Cambridge

Collins M, Sutherland M, Bouwer L, Cheong SM, Frölicher T, Jacot Des Combes H, Roxy MK, Losada I, McInnes K, Ratter B, Rivera-Arriga E, Susanto RD, Swingedouw D, Tibig L (2019) Extremes, abrupt changes and managing risks. In: Portner et al (eds) IPCC special report on oceans and cryosphere in a changing climate. Cambridge University Press, Cambridge

Deepa JS, Gnanaseelan C, Mohapatra S, Chowdary JS, Karmakar A, Kakatkar R, Parekh A (2019) The tropical Indian Ocean decadal sea level response to the Pacific decadal oscillation forcing. Clim Dyn 52:5045-5058. https://doi.org/10.1007/s00382-018-4431-9 
Deser C, Phillips AS, Alexander MA (2010) Twentieth century tropical sea surface temperature trends revisited. Geophys Res Lett 37: L10701. https://doi.org/10.1029/2010GL043321

Dong L, McPhaden MJ (2016) Interhemispheric SST gradient trends in the Indian Ocean prior to and during the Recent global warming hiatus. J Clim 29:9077-9095. https://doi.org/10.1175/JCLI-D-160130.1

Dong L, Zhou T, Wu B (2014) Indian Ocean warming during 19582004 simulated by a climate system model and its mechanism. Clim Dyn 42:203-217. https://doi.org/10.1007/s00382-013-1722-Z

Dong L, Zhou T (2014) The Indian Ocean sea surface temperature warming simulated by CMIP5 models during the twentieth century: competing forcing roles of GHGs and anthropogenic aerosols. J Clim 27(9):3348-3362

Dore JE, Lukas R, Sadler DW, Church MJ, Karl DM (2009) Physical and biogeochemical modulation of ocean acidification in the central North Pacific. Proc Natl Acad Sci USA 106:12235-12240

Du Y, Xie S-P (2008) Role of atmospheric adjustments in the tropical Indian Ocean warming during the 20th century in climate models. Geophys Res Lett 35:L08712. https://doi.org/10.1029/ 2008GL033631

Du Y, Xie S-P, Huang G, Hu K (2009) Role of air-sea interaction in the long persistence of El Niño-induced north Indian Ocean warming. J Clim 22(8):2023-2038. https://doi.org/10.1175/2008JCLI2590.1

Fasullo JT, Otto-Bliesner BL, Stevenson S (2018) ENSO's changing influence on temperature, precipitation, and wildfire in a warming climate. Geophys Res Lett 45:9216-9225. https://doi.org/10.1029/ 2018GL079022

Gastineau G, Friedman AR, Khodri M, Vialard J (2018) Global ocean heat content redistribution during 1998-2012 Interdecadal Pacific Oscillation negative phase. Clim Dyn 53:1187-1208. https://doi. org/10.1007/s00382-018-4424-8

Gnanaseelan C, Roxy MK, Deshpande A (2017) Variability and trends of sea surface temperature and circulation in the Indian Ocean. In: Rajeevan MN, Nayak S (eds) Observed climate variability and change over the Indian Region, vol 10. Springer, Singapore, pp 165-179. Doi:10.1007/978-981-10-2531-0

Graham NE, Barnett TP (1987) Sea surface temperature, surface wind divergence, and convection over tropical oceans. Science 238 (4827):657-659

Gille ST (2002) Warming of the Southern Ocean since the 1950s. Science 295(5558):1275-1277

Han W, Vialard J, McPhaden MJ, Lee T, Masumoto Y, Feng M, De Ruijter WP (2014) Indian Ocean decadal variability: a review. Bull Amer Meteor Soc 95(11):1679-1703. https://doi.org/10.1175/ BAMS-D-13-00028.1

Helly JJ, Levin LA (2004) Global distribution of naturally occurring marine hypoxia on continental margins. Deep-Sea Res I 51:11591168

Hu S, Fedorov AV (2019) Indian Ocean warming can strengthen the Atlantic meridional overturning circulation. Nat Clim Chang 9:747751

Hughes TP et al (2018) Global warming transforms coral reef assemblages. Nature 556:492-496. https://doi.org/10.1038/s41586018-0041-2

IPCC (2014) Climate change 2014: synthesis report. Contribution of working groups I, II and III to the fifth assessment report of the intergovernmental panel on climate change, vol 151. IPCC, Geneva, Switzerland. (Core Writing Team, Pachauri RK, Meyer LA (eds))

Izumo T, Montégut CB, Luo JJ, Behera SK, Masson S, Yamagata T (2008) The role of the western Arabian Sea upwelling in Indian monsoon rainfall variability. J Clim 21(21):5603-5623

Jin X, Kwon Y, Ummenhoffer CC, Seo H, Schwarzkopf FU, Biastoch A, Boning CW, Wright JS (2018) Influence of Pacific climate variability on decadal subsurface ocean heat content in the
Indian Ocean. J Clim 31:4157-4171. https://doi.org/10.1175/JCLID-17-0654.1

Keeling RF, Arne Körtzinger A, Gruber N (2010) Ocean deoxygenation in a warming world. Annu Rev Mar Sci 2:199-229

Klein SA, Soden BJ, Lau NC (1999) Remote sea surface temperature variations during ENSO: evidence for a tropical atmospheric bridge. J Clim 12:917-932. https://doi.org/10.1175/1520-0442(1999) 012,0917:RSSTVD.2.0.CO;2

Koslow JA, Goericke R, Lara-Lopez A, Watson W (2011) Impact of declining intermediate-water oxygen on deepwater fishes in the California Current. Mar Ecol-Prog Ser 436:207-218

Kouketsu S, Kawano T, Masuda S, Sugiura N, Sasaki Y, Toyoda T, Igarashi H, Kawai Y, Katsumata K, Uchida H, Fukasawa M (2011) Deep ocean heat content changes estimated from observation and reanalysis product and their influence on sea level change. J Geophys Res 116:C03012. https://doi.org/10.1029/2010JC006464

Kumar A, Wen CH (2016) An oceanic heat content-based definition for the Pacific decadal oscillation. Mon Weather Rev 144(10):39773984. https://doi.org/10.1175/mwr-d-16-0080.1

Lau NC, Nath MJ (2000) Impact of ENSO on the variability of the Asian-Australian monsoons as simulated in GCM experiments. J Clim 13(24):4287-4309. https://doi.org/10.1175/1520-0442 (2000)013\%3c4287:IOEOTV\%3e2.0.CO;2

Lee P-F, Chen I-C, Tzeng W-N (2005) Spatial and temporal distribution patterns of bigeye tuna (Thunnus obesus) in the Indian Ocean. Zool Stud Taipei 44(2):260

Lee SK, Park W, Baringer M, Gordon AL, Huber B, Liu Y (2015) Pacific origin of the abrupt increase in Indian Ocean heat content during the warming hiatus. Nat Geosci 8:445-449. https://doi.org/ 10.1038/NGEO2438

Levitus S, Antonov JI, Boyer TP, Locarnini RA, Garcia HE, Mishonov AV (2009) Global ocean heat content 1955-2008 in light of recently revealed instrumentation problems. Geophys Res Lett 36:L07608. https://doi.org/10.1029/2008GL037155

Levitus S, Antonov JI, Wang J, Delworth TL, Dixon KW, Broccoli AJ (2001) Anthropogenic warming of earth's climate system. Science 292(5515):267-270. https://doi.org/10.1126/science.1058154

Li G, Xie S-P, Du Y (2016) A robust but spurious pattern of climate change in model projections over the tropical Indian Ocean. J Clim 29:5589-5608. https://doi.org/10.1175/JCLI-D-15-0565.1

Liu W, Xie SP, Lu J (2016) Tracking ocean heat uptake during the surface warming hiatus. Nat Commun 7:10926. https://doi.org/10. 1038/ncomms 10926

Li Y, Han W, Hu A, Meehl GA, Wang F (2018) Multidecadal changes of the upper Indian Ocean heat content during 1965-2016. J Clim 31:7863-7884. https://doi.org/10.1175/JCLI-D-18-0116.1

Mishra V, Smoliak BV, Lettenmaier DP, Wallace JM (2012) A prominent pattern of year-to-year variability in Indian Summer Monsoon Rainfall. Proc Natl Acad Sci 109(19):7213-7217

Mohapatra S, Gnanaseelan C, Deepa JS (2020) Multidecadal to decadal variability in the equatorial Indian Ocean subsurface temperature and the forcing mechanisms. Clim Dyn 54:3475-3487. https://doi. org/10.1007/s00382-020-05185-7

Nagamani PV, Ali MM, Goni GJ, Bhaskar TU, McCreary JP, Weller RA, Rajeevan M, Krishna VG, Pezzullo JC (2016) Heat content of the Arabian Sea Mini Warm Pool is increasing. Atmos Sci Lett 17(1):39-42. https://doi.org/10.1002/asl.596

Oliver ECJ et al (2018) Longer and more frequent marine heatwaves over the past century. Nat Commun 9:1324. https://doi.org/10.1038/ s41467-018-03732-9

Palmer MD, Roberts CD, Balmaseda M, Chang YS, Chepurin G, Ferry N, Fujii Y, Good SA, Guinehut S, Haines K, Hernandez F (2017) Ocean heat content variability and change in an ensemble of ocean reanalyses. Clim Dyn 49(3):909-930. https://doi.org/10. 1007/s00382-015-2801-0 
Pratik K, Parekh A, Karmakar A, Chowdary JS, Gnanaseelan C (2019) Recent changes in the summer monsoon circulation and their impact on dynamics and thermodynamics of the Arabian Sea. Theor Appl Climatol 136:321-331. https://doi.org/10.1007/s00704-018-2493-6

Purkey SG, and Johnson GC (2010) Warming of global abyssal and deep Southern Ocean waters between the 1990s and2000s: Contributions to global heat and sea level rise budgets. J Climate 23 (23):6336-6351

Rahul S, Gnanaseelan C (2013) Net heat flux over the Indian Ocean: Trends, driving mechanisms, and uncertainties. IEEE Geosci Remote Sens Lett 10(4):776-780. https://doi.org/10.1109/LGRS. 2012.2223194

Rahul S, Gnanaseelan C (2016) Can large scale surface circulation changes modulate the sea surface warming pattern in the Tropical Indian Ocean? Clim Dyn 46(11):3617-3632. https://doi.org/10. 1007/s00382-015-2790-z

Rosenthal Y, Kalansky J, Morley A, Linsley BK (2017) A paleo-perspective on ocean heat content: lessons from the Holocene and Common Era. Quat Sci Rev 155:1-2

Rajeevan M, Srinivasan J, Niranjan Kumar K, Gnanaseelan C, Ali MM (2013) On the epochal variation of intensity of tropical cyclones in the Arabian Sea. Atmos Sci Lett 14(4):249-255

Rao SA, Dhakate AR, Saha SK, Mahapatra S, Chaudhari HS, Pokhrel S, Sahu SK (2012) Why is Indian Ocean warming consistently? Clim Change 110:709-719. https://doi.org/10.1007/ s10584-011-0121-x

Rodrigues RR, Taschetto AS, Gupta AS, Foltz GR (2019) Common cause for severe droughts in South America and marine heatwaves in the South Atlantic. Nat Geosci 12(8):620-626

Rohini P, Rajeevan M, Srivastava AK (2016) On the variability and increasing trends of heat waves over India. Scientific reports 6:26153

Roxy MK, Ghosh S, Pathak A, Athulya R, Mujumdar M, Murtugudde R, Terray P, Rajeevan M (2017) A threefold rise in widespread extreme rain events over central India. Nat Commun 8:78

Roxy MK, Dasgupta P, McPhaden MJ, Suematsu T, Zhang C, Kim D (2019) Twofold expansion of the Indo-Pacific warm pool warps the MJO lifecycle. Nature 575:647-651. https://doi.org/10.1038/ s41586-019-1764-4

Roxy MK, Modi A, Murtugudde R, Valsala V, Panickal S, Prasanna Kumar S, Ravichandran M, Vichi M, Lévy M (2016) A reduction in marine primary productivity driven by rapid warming over the tropical Indian Ocean. Geophys Res Lett 43(2):826-833. https://doi. org/10.1002/2015GL066979

Roxy MK, Ritika K, Terray P, Masson S (2014) The curious case of Indian Ocean warming. J Clim 27(22):8501-8509. https://doi.org/ 10.1175/JCLI-D-14-00471.1

Sabeerali CT, Rao SA, George G, Rao DN, Mahapatra S, Kulkarni A, Murtugudde R (2014) Modulation of monsoon intraseasonal oscillations in the recent warming period. J Geophys Res Atmos 119(9):5185-5203

Sabine CL, Freely RA, Gruber N, Key RM, Lee K, Bullister JL, Wanninkhof R, Wong CS, Wallace DWR, Tilbrook B, Millero FJ, Peng T-H, Kozyr A, Ono T, Rios AF (2004) The oceanic sink for anthropogenic $\mathrm{CO}_{2}$. Science 305:367-371

Saha A, Ghosh S, Sahana AS, Rao EP (2014) Failure of CMIP5 climate models in simulating post-1950 decreasing trend of Indian monsoon. Geophys Res Lett 41(20):7323-7330

Saji NH, Goswami BN, Vinayachandran PN, Yamagata T (1999) A dipole mode in the tropical Indian Ocean. Nature 401:360-363

Sayantani O, Gnanaseelan C (2015) Tropical Indian Ocean subsurface temperature variability and the forcing mechanisms. Clim Dyn 44:2447-2462. https://doi.org/10.1007/s00382-014-2379-y
Schmidtko S, Stramma L, Visbeck M (2017) Decline in global oceanic oxygen content during the past five decades. Nature 542:335-339. https://doi.org/10.1038/nature21399

Singh D, Ghosh S, Roxy MK, McDermid S (2019) Indian summer monsoon: extreme events, historical changes, and role of anthropogenic forcings. Wiley Interdiscip Rev Clim Chang 10(2):e571

Slangen ABA, Carson M, Katsman CA, van de Wal RSW, Koehl A, Vermeersen LLA, Stammer D (2014) Projecting twenty-first century regional sea-level changes. Clim Change 124:317-332. https://doi.org/10.1007/s10584-014-1080-9

Smith D, Murphy JM (2007) An objective ocean temperature and salinity analysis using covariances from a global climate model. J Geophys Res Oceans 112(C2)

Sreeush MG, Rajendran S, Valsala V, Pentakota S, Prasad KV, Murtugudde R (2019a) Variability, trend and controlling factors of Ocean acidification over Western Arabian Sea upwelling region. Marine Chem. https://doi.org/10.1016/j.marchem.2018.12.002. (2018)

Sreeush MG, Valsala V, Santanu H, Pentakota S, Prasad KVSR, Naidu CV, Murtugudde R (2019b) Biological production in the Indian Ocean upwelling zones-part 2: data based estimates of variable compensation depth for ocean carbon models via cyclo-stationary Bayesian inversion, deep sea research part II: topical studies in oceanography, 2019, ISSN 0967-0645. https://doi. org/10.1016/j.dsr2.2019.07.007

Srinivasu U, Ravichandran M, Han W, Sivareddy S, Rahman H, Li Y, Nayak S (2017) Causes for the reversal of north Indian Ocean decadal sea level trend in recent two decades. Clim Dyn 49:38873904. https://doi.org/10.1007/s00382-017-3551-y

Stramma L, Johnson GC, Sprintall J, Mohrholz V (2008) Science 320 (5876):655-658. https://doi.org/10.1126/science.1153847

Ummenhofer CC, Biastoch A, Böning CW (2017) Multidecadal Indian Ocean variability linked to the Pacific and implications for preconditioning Indian Ocean dipole events. J Clim 30(5):17391751. https://doi.org/10.1175/JCLI-D-16-0200.1

Valsala V, Murtugudde R (2015) Mesoscale and intraseasonal air-sea $\mathrm{CO}_{2}$ exchanges in the western Arabian Sea during boreal summer. Deep Sea Res Part I 103:101-113

Von Schuckmann K, Sallée JB, Chambers D, Le Traon PY, Cabanes C, Gaillard F, Speich S, Hamon M (2014) Monitoring ocean heat content from the current generation of global ocean observing systems. Ocean Sci 10:547-557. https://doi.org/10.5194/os-10-5472014

Webster PJ, Moore AM, Loschnigg JP, Leben RR (1999) Coupled ocean-atmosphere dynamics in the Indian Ocean during 1997-1998. Nature 401:356-360

Xie S-P, Annamalai H, Schott FA, McCreary JP Jr (2002) Structure and mechanisms of South Indian Ocean climate variability. J Clim 15:864-878

Xue Y et al (2012) A comparative analysis of upper-ocean heat content variability from an ensemble of operational ocean reanalyses. J Clim 25:6905-6929. https://doi.org/10.1175/JCLI-D-11-00542.1

Zanna L, Khatiwala S, Gregory JM, Ison J, Heimbach P (2019) Global reconstruction of historical ocean heat storage and transport. Proc Natl Acad Sci 116(4):1126-1131

Zhao Y, Zhang H (2016) Impacts of SST warming in tropical Indian Ocean on CMIP5 model-projected summer rainfall changes over Central Asia. Clim Dyn 46:3223-3238. https://doi.org/10.1007/ s00382-015-2765-0

Zheng XT, Xie S (2009) Indian Ocean dipole response to global warming: analysis of ocean-atmospheric feedbacks in a coupled model. J Clim 23:1240-1253. https://doi.org/10.1175/ 2009JCLI3326.1 
Open Access This chapter is licensed under the terms of the Creative Commons Attribution 4.0 International License (http:// creativecommons.org/licenses/by/4.0/), which permits use, sharing, adaptation, distribution and reproduction in any medium or format, as long as you give appropriate credit to the original author(s) and the source, provide a link to the Creative Commons license and indicate if changes were made.
The images or other third party material in this chapter are included in the chapter's Creative Commons license, unless indicated otherwise in a credit line to the material. If material is not included in the chapter's Creative Commons license and your intended use is not permitted by statutory regulation or exceeds the permitted use, you will need to obtain permission directly from the copyright holder. 